\title{
Marketing Alliances, Firm Networks, and Firm Value Creation
}

Prior research has found that the announcement of marketing alliances tends to produce no effect on firm value creation in a high-tech context. This article reexamines this issue and investigates whether the characteristics of a firm's network of alliances affect the firm value created from the announcement of a new marketing alliance. The authors investigate whether network centrality, network density, network efficiency, network reputation, and marketing alliance capability influence firm value creation. They examine this question using an event study of 230 announcements for marketing alliances in the software industry. The results indicate that, in general, marketing alliance announcements create value (i.e., abnormal stock returns) for the firm in the announcement period event window. Furthermore, network efficiency and network density have the strongest positive impact when they are moderate; network reputation and network centrality have no effect. These results point to the greater role of relational network characteristics than size-/status-based benefits. Finally, marketing alliance capability, which reflects a firm's ability to manage a network of previous marketing alliances, has a positive impact on value creation.

Keywords: marketing alliances, networks, alliance capability, relationship marketing, stock market effects, event study

$\mathbf{M}$ arketing has a long tradition of examining dyadic exchange relationships involving buyer-seller relationships (e.g., Heide 1994; Palmatier 2008) and strategic alliances (e.g., Bucklin and Sengupta 1993). However, research in this area has lagged in two respects. First, in general, research has not examined how marketing alliances affect the value of the firm. Although a few exceptions exist (e.g., Houston and Johnson 2000; Kalaignanam, Shankar, and Varadarajan 2007), most marketing alliance research has examined relational outcomes (e.g., Anderson and Weitz 1992; Dwyer, Schurr, and Oh 1987), revenue outcomes (Luo, Rindfleisch, and Tse 2007), and innovation outcomes (Rindfleisch and Moorman 2001). Given this gap and the large investment firms make in selecting and managing marketing alliance partners, examining the effect of marketing alliances on firm value is our first research objective.

Second, it is increasingly common to find firms involved in multiple and interconnected alliances with upstream suppliers or downstream buyers (i.e., vertical relationships) and alliances with other firms at a similar level of the value chain (i.e., horizontal relationships). These com-

Vanitha Swaminathan is Associate Professor of Marketing, Katz Graduate School of Management, University of Pittsburgh (e-mail: vanitha@katz. pitt.edu). Christine Moorman is T. Austin Finch, Sr. Professor of Marketing, Fuqua School of Business, Duke University (e-mail: moorman@duke. edu). The authors thank the four anonymous JM reviewers for their constructive suggestions and the Marketing Science Institute for financially supporting this research. The authors gratefully acknowledge Leonce Bargeron, Alon Brav, Bill Greene, Ravi Madhavan, Carl Mela, and Shawn Thomas for their suggestions for improving this article. plex relational forms are referred to as "networks" (e.g., Achrol and Kotler 1999; Gulati 1999; Webster 1992). Networks are often viewed as a key strategic resource (Van den Bulte and Wuyts 2007; Webster 1992). Despite this importance, existing research has not examined how a firm's network of partnerships influences the value created from the announcement of a new marketing alliance. This is our second objective.

This study examines how firm network features influence the value from a new marketing alliance. Specifically, we consider whether (1) the firm has connections with other firms (i.e., network centrality), (2) the firm's network provides firm access to new capabilities (i.e., network efficiency), (3) the firm's network involves interconnections among firms (i.e., network density), (4) the firm's network has a strong reputation (i.e., network reputation), and (5) the firm has a proven ability to manage its prior network of marketing alliances (i.e., marketing alliance capability).

Our approach departs from prior research, which has focused on how firm network characteristics influence the firm's ability to form relationships with high-profile partners (Gulati 1999; Hitt et al. 2000). Instead, even after accounting for the ability of networks to attract partners, we provide new evidence that firm network characteristics play a direct role in extracting value from a marketing alliance.

We begin by examining the question whether the stock market rewards firms for announcing marketing alliances in general. Our approach involves an event study that captures the immediate short-term reaction of the stock market to the alliance announcement rather than a measure of long-term firm value creation from the alliance. We then consider how a firm's network of alliances influences these abnormal returns. 


\section{Do Marketing Alliance Announcements Increase Firm Abnormal Returns?}

Marketing alliances are formalized collaborative arrangements between two or more organizations focused on downstream value chain activities (Das, Sen, and Sengupta 1998; Rindfleisch and Moorman 2001). Consistent with recent research on the impact of marketing activities on firm value (e.g., Geyskens, Gielens, and Dekimpe 2002; Mizik and Jacobson 2003; Rust et al. 2004), we posit that marketing alliances can increase firm value in several key ways. First, a marketing alliance gives the firm access to new markets (Bucklin and Sengupta 1993). For example, by forming an alliance with a well-entrenched retailer, a firm gains access to the retailer's customers. This access can increase the level and speed of firm cash flows. Second, a marketing alliance provides a firm with access to entire products, product features, brands, or services (Kalaignanam, Shankar, and Varadarajan 2007). Such access can help the firm create stronger offerings, which can increase customer acquisition, satisfaction, and retention and associated cash flows. Third, a marketing alliance supplies a firm with access to new knowledge and skills (Rindfleisch and Heide 1997). Such access means that firms do not need to develop these internally. Thus, cash flow levels due to lower costs and cash flow speed increase because the firm is accessing existing resources.

Despite these valuable contributions, little research has examined whether marketing alliances contribute to abnormal returns. In marketing, Houston and Johnson (2000) find that firm returns from governance choice (i.e., contract versus joint venture) in buyer-seller alliances depend on supplier investments and the ability to monitor partners. Kalaignanam, Shankar, and Varadarajan (2007) find that new product development alliances (some of which also involve marketing activities) improve firm shareholder value. In strategy, Das, Sen, and Sengupta (1998) find a null effect for marketing alliances, and Koh and Venkatraman (1991) observe a null effect for marketing joint ventures on firm abnormal returns. ${ }^{1}$

These null effects may be due to the samples including a range of industries (18 in Das, Sen, and Sengupta [1998] and 11 in Koh and Venkatraman [1991]) rather than a specific industry, such as the high-tech industry in Kalaignanam, Shankar, and Varadarajan's (2007) study. In the absence of industry controls, the impact of marketing alliances may be obscured by sample heterogeneity (Bass, Cattin, and Wittink 1978). These null effects may also be because these studies were conducted on data from more than 20 years ago (1987-1991 in Das, Sen, and Sengupta [1998] and 1972-1986 in Koh and Venkatraman [1991]) versus Kalaignanam, Shankar, and Varadarajan's (19932004) study. Over time, the contributions of marketing to the firm have advanced considerably.

${ }^{1}$ Das, Sen, and Sengupta (1998) focus on marketing and technology alliance differences. In their research, the effect of technology alliances on returns is positive and greater than marketing alliances, and the effect of marketing alliances is not significant.
Given the importance of marketing alliances, the paucity of research on the impact of marketing alliances on value creation, and the shortcomings of the available studies, we investigate this issue again. Consistent with our previous arguments, we expect that the announcement of marketing alliances results in a positive reaction from the stock market. Thus, we posit the following: ${ }^{2}$

$\mathrm{H}_{1}$ : The announcement of a marketing alliance creates positive firm abnormal returns.

\section{Do Firm Networks Influence Firm Abnormal Returns from Marketing Alliance Announcements?}

\section{Value Creation Mechanisms}

Firm networks influence abnormal returns from marketing alliance announcements through three mechanisms. These mechanisms, which are derived from literature on the resource-based view of the firm and literature on marketbased assets, play a role across the specific network characteristics we subsequently discuss.

First, networks multiply alliance benefits. Anderson, Håkansson, and Johanson (1994) refer to this as the transferability mechanism of networks. Alliance-to-network transfers multiply the value created in the announced alliance because the firm deploys or replicates the value across geographies, industries, markets, or product lines in the firm's network. Network-to-alliance transfers multiply the value created in the announced alliance because the firm uses information and other resources from the network to create value in the announced alliance (Cohen and Levinthal 1990). When transfers of either type are effective, networks can help firms lock out competition and create dominant standards, particularly in markets (e.g., computer software) in which network externalities are crucial to consumers' adoption of products and services (Frels, Shervani, and Srivastava 2003). These multiplier mechanisms play a role in network centrality, efficiency, and reputation and in the firm's ability to create value from its network of previous alliances.

Second, networks facilitate alliance compliance. When networks increase the pressure on a new partner to cooperate, to follow rules, and/or to conform to standards or norms, the firm needs to exert less pressure or to engage in less monitoring (Heide, Wathne, and Rokkan 2007). Compliance occurs because partners fear sanctions (due to network density), because partners conform to the requests of a central or high-reputation network player, or because partners are not competing in the same industry (due to network efficiency).

Third, networks signal firm and alliance quality. Creating value from an alliance is not easy, and most alliances fail (Gulati and Kletter 2005). Thus, the existence of a network provides information about the firm's ability to sus-

${ }^{2}$ Consistent with the event study approach, all our predictions and tests involve the immediate returns accruing to the firm during the event window surrounding the announcement. 
tain alliances. Furthermore, a network is difficult for competitors to replicate and to substitute with alternative resources (Barney 1991; Peteraf 1993). Finally, networks can serve as a barrier to entry. This mechanism plays a role in network centrality, in network reputation, and in the overall ability of a firm to generate better value from its network of marketing alliances over time.

Using the logic of these three mechanisms, we now offer formal hypotheses that link firm network characteristics to firm abnormal returns from a marketing alliance announcement. Figure 1 provides a graphic illustration of the network variables we examine.

\section{Network Centrality}

Three aspects of network centrality have been widely adopted: degree, closeness, and betweenness (Freeman 1979; Houston et al. 2004). We focus on degree centrality, or the number of firms to which a firm is directly connected. ${ }^{3}$ Research shows that central actors tend to select good partners (Gulati 1998, 1999; Podolny and Stuart 1995; Powell, Koput, and Smith-Doerr 1996). However, beyond its effects on partner selection, how does network centrality enhance firm abnormal returns from a new alliance?

First, network centrality gives the firm an opportunity to multiply alliance benefits through both alliance-to-network transfers and network-to-alliance transfers. Alliance-tonetwork transfers can offer substantial opportunities for growth as the central firm applies the particular product or activity from the new alliance across its network (Capaldo 2007; Grewal, Lilien, and Mallapragada 2006). For example, IBM used its alliance with Nortel to identify new datanetworking solutions, which it applied to its network of hardware and software vendors to create industry standards for enterprise data centers. Network-to-alliance transfers offer the central firm the opportunity to apply marketing processes or technologies developed in the network for the benefit of the alliance (Gulati 1998; Powell, Koput, and Smith-Doerr 1996). For example, Eli Lilly applied experience from its network of alliances to create a successful alliance with ICOS when developing the drug Cialis.

Second, a central position reflects more social capital (Burt 2000) or status (Podolny 1993). As a result, alliance partners infer that a central network position means that the firm can wield power and influence. As a result, partners are likely to grant a central firm more bargaining power, which enables the firm to design the new relationship for stronger financial performance. For these reasons, we hypothesize the following:

\footnotetext{
$\mathrm{H}_{2}$ : There is a positive relationship between firm network centrality and firm abnormal returns due to a marketing alliance announcement.
}

\footnotetext{
${ }^{3}$ Network centrality as closeness (i.e., the distance between firms in a network; Bond et al. 2004) and betweenness (i.e., the degree to which a firm is positioned on the shortest path between pairs of other firms; Tsai and Ghoshal 1998) has also been examined. We selected degree centrality given our focus on a firm's ego network of alliances as the unit of analysis. Closeness and betweenness centrality are more relevant when focusing on the entire network as the unit of analysis.
}

FIGURE 1 Network Characteristics and Definitions

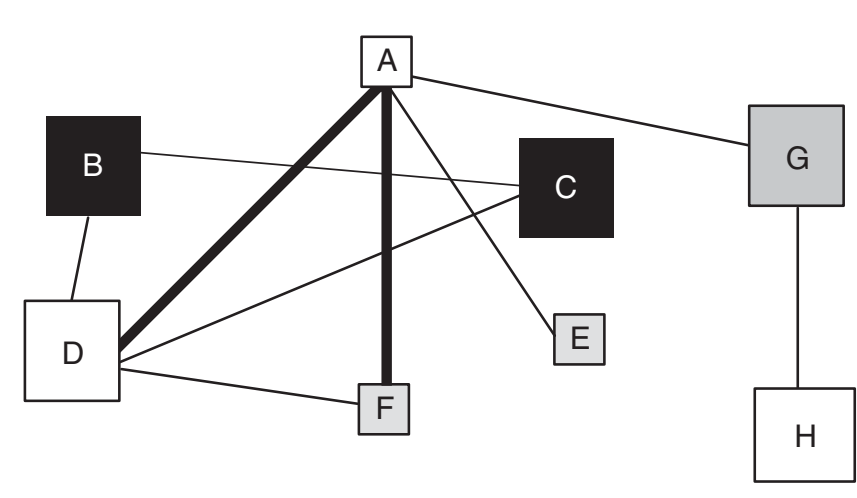

Key:

-Boxes represent firms.

-Box shade signifies the firm's industry membership. -Box size signifies the firm's reputation.

- Lines represent the existence of an alliance between two firms.

-Line heaviness reflects the strength of the alliance between two firms (not examined herein).

Network centrality: The number of firms with which a firm is directly connected. Firms A and D are the most central, and Firms $\mathrm{E}$ and $\mathrm{H}$ are the least central.

Network efficiency: The degree to which the firm's network of alliances involves firms that possess nonredundant knowledge, skills, and capabilities. Firms $B$ and $C$ have the most efficient network, and Firms E, F, G, and $H$ have the least.

Network density: The degree of interconnectedness among various actors in a network. Firms $B, C$, and $F$ have the densest networks, and Firms E, G, and $\mathrm{H}$ have the least.

Network reputation: The aggregate-level quality ascribed to organizations in a firm's network. If we assume that the large boxes (i.e., Firm G) have a reputation score of 1 and the small boxes have a reputation score of 0 , the average network reputation is highest for Firms $\mathrm{B}, \mathrm{C}$, and $\mathrm{H}$ and lowest for Firm E.

\begin{tabular}{|c|c|c|c|c|c|c|c|c|}
\hline \multirow{2}{*}{$\begin{array}{l}\text { Network } \\
\text { Characteristics }\end{array}$} & \multicolumn{8}{|c|}{ Firms in Networks } \\
\hline & $\mathbf{A}$ & B & C & D & $\mathbf{E}$ & $\mathbf{F}$ & $\mathbf{G}$ & $\mathbf{H}$ \\
\hline $\begin{array}{l}\text { Network } \\
\text { centrality } \\
\text { Network }\end{array}$ & 4 & 2 & 2 & 4 & 1 & 2 & 2 & 1 \\
\hline $\begin{array}{l}\text { efficiencya } \\
\text { Network }\end{array}$ & .09 & .25 & .25 & .16 & .00 & .00 & .00 & .00 \\
\hline $\begin{array}{l}\text { density } \\
\text { Network }\end{array}$ & .17 & 1.00 & 1.00 & .33 & .00 & 1.00 & .00 & .00 \\
\hline reputation & .50 & 1.00 & 1.00 & .50 & .00 & .50 & .50 & 1.00 \\
\hline
\end{tabular}

aThe focal firm's industry is ignored in this analysis.

\section{Network Efficiency}

Network efficiency refers to the degree to which the firm's network of alliances involves firms that possess nonredundant knowledge, skills, and capabilities (Baum, Calabrese, and Silverman 2000; Burt 2004; Granovetter 1973). How does network efficiency influence firm abnormal returns from a new alliance announcement? 
On the positive side, highly efficient networks increase firm exposure to novel information from allying with firms from different industries (Baum, Calabrese, and Silverman 2000; Beckman and Haunschild 2002; Powell, Koput, and Smith-Doerr 1996; Schilling and Phelps 2007; Uzzi 1996, 1997). In turn, this increases the likelihood that the firm will find additional opportunities to transfer what it has learned in the new alliance to other network members and to bring novel new resources to bear on its management of the new alliance. Both increase the benefits the firm derives from the newly announced alliance. Aiding these transfers is the lack of competition for the same customers between firms in efficient networks, which increases motivation to cooperate (Rindfleisch and Moorman 2001). On the negative side, these differences also reduce the ability to cooperate because knowledge is unique and goals are not shared among network members (Galaskiewicz 1985; Goerzen and Beamish 2005; Rindfleisch and Moorman 2001). Therefore, although highly efficient networks enhance firm access to novel information, this information may be too different from the firm's strategies and goals to be useful in the new alliance.

Thus, a moderate amount of network efficiency may have the most positive effect on firm abnormal returns from the new alliance. Consistent with this, research has demonstrated that moderate levels of network efficiency result in the highest levels of firm innovation (Baum, Calabrese, and Silverman 2000; Wuyts, Stremersch, and Dutta 2004). Firms with moderate levels of network efficiency also balance the costs of dependence with the benefits of a lean and focused set of partners. A highly efficient network means that the firm has alliances with a small number of partners from any one industry, which increases the risk of being locked in with an unsuccessful alliance partner if the relationship fails. Given this risk, it is not surprising that firms such as Microsoft use a strategy of establishing multiple partnerships to serve the same function, which reduces network efficiency (Gulati, Nohria, and Zaheer 2000). However, low levels of network efficiency can also have significant disadvantages by fostering learning races or unhealthy competition between redundant partners.

For all these reasons, a moderate level of network efficiency is likely to produce the highest levels of value from the new alliance. At moderate levels, the firm gains the benefits of network redundancy without creating corresponding inefficiencies and risks. Thus, we predict the following:

$\mathrm{H}_{3}$ : There is an inverted U-shaped relationship between firm network efficiency and firm abnormal returns due to a marketing alliance announcement.

\section{Network Density}

Network density refers to the degree of interconnectedness among various actors in a network (Coleman 1988, 1990). High network density brings two key advantages to the new marketing alliance. First, because all partners are connected, high-quality information can be easily disseminated in dense networks (Lee 2007; Uzzi 1997). Network-toalliance transfers and alliance-to-network transfers function effectively, which increases the value of the new alliance. Second, network density reduces the likelihood that the new partner will behave opportunistically (Antia and Frazier 2001; Coleman 1988). The collective monitoring and sanctioning associated with a dense network acts as a check on new partner behavior (Kreps 1990; Rowley, Behrens, and Krackhardt 2000; Walker, Kogut, and Shan 1997). As a result, the firm needs to invest less in monitoring the new alliance to achieve coordination (Rindfleisch and Heide 1997). 4

Despite these benefits, dense networks bring two distinct disadvantages that may reduce the value of the newly announced alliance. Given that more information is shared in dense networks, the firm may have less flexibility to adopt a distinct strategy that is optimal for the new alliance. Relatedly, the high level of information sharing also makes it difficult for firms to adopt a strategy of selectively sharing sensitive information with different partners to maximize the value of the alliance. For example, a firm may want to share secrets with the new partner to induce reciprocal sharing but not with other partners that have less to share.

Given these contrasting viewpoints, moderate network density is likely to be optimal. In summary, high density levels improve information transfers between the network and the new alliance and reduce new partner opportunism. However, high levels also reduce firm flexibility in managing the new alliance. Conversely, low levels reduce information transfers and increase new partner opportunism but increase firm flexibility to act unilaterally with the new partner. Given these trade-offs, we hypothesize a nonlinear effect in which moderate density provides the optimal benefit to a firm announcing a new alliance.

\footnotetext{
$\mathrm{H}_{4}$ : There is an inverted U-shaped relationship between firm network density and firm abnormal returns due to a marketing alliance announcement.
}

\section{Network Reputation}

Reputation is an intangible quality ascribed by other actors in a social system that is determined by the actor's past actions (Coleman 1988; Podolny 1993; Raub and Weesie 1990). Thus, firm network reputation is the aggregate-level quality ascribed to organizations in a firm's network. Reputation can spill over to boost the perceived quality of associated actors (Megginson and Weiss 1991). Reputation can also limit false claims as actors attempt to maintain the integrity of the quality signal (Rao, Qu, and Ruekert 1999).

Given these theoretical rationales, positive spillovers and signals from a firm's high-reputation network can improve value creation from a new marketing alliance for several reasons. First, the firm's high-reputation network may spill over to the new alliance. Second, the firm's highreputation network may also signal that the firm has knowl-

\footnotetext{
${ }^{4}$ Although the opportunism-curbing effects of network density are greater when the new partner is deeply embedded in the firm's network, our predicted effect does not depend on this, because the new partner should be motivated to maintain its reputation in the industry for future alliances as well. Negative information in the firm's dense network could hurt these future alliance prospects.
} 
edge and skills for managing alliances, which will increase investors' belief that the firm will be successful in the new alliance (Anderson, Håkansson, and Johanson 1994). Third, a high-reputation network puts pressure on the firm to perform well in the new alliance to maintain the quality signal. We hypothesize the following:

$\mathrm{H}_{5}$ : There is a positive relationship between network reputation and firm abnormal returns due to a marketing alliance announcement.

\section{Marketing Alliance Capability}

Marketing alliance capability refers to the ability of firms to generate higher returns from marketing alliances over time. Although it is not a network characteristic in the literature (Van den Bulte and Wuyts 2007), marketing alliance capability is a network-level view of the firm's ability to extract greater levels of value from alliances over time. Scholars have examined firm capabilities associated with alliance partner selection and alliance management as a key factor in alliance success (Gulati 1998; Kale, Dyer, and Singh 2002; Khanna, Gulati, and Nohria 1998). Thus, we focus on how marketing alliance capability influences value creation from a new alliance.

Marketing alliance capability influences value creation from a marketing alliance announcement in two ways. First, the capability is a signal of firm quality. Thus, the stock market should infer that a firm with a strong marketing alliance capability from its network of past alliances will extract value from the current alliance as well. Second, the capability reflects a firm's success in managing alliances among its network of partnerships. Thus, investors may infer that the firm will have more opportunity to multiply the benefits from the new marketing alliance across a broader network of previous alliance partners. In turn, this can enhance the ratio of private (relative to common) benefits a firm generates in a given marketing alliance (Gulati, Nohria, and Zaheer 2000). When accrued over time, these private benefits can help a firm lock out competition (Frels, Shervani, and Srivastava 2003). Therefore, we posit the following:

$\mathrm{H}_{6}$ : There is a positive relationship between firm marketing alliance capability and firm abnormal returns due to a marketing alliance announcement.

\section{Method}

\section{Data Sources}

We drew data on strategic alliances from the SDC Joint Ventures \& Strategic Alliances database. SDC provides descriptions of alliances and participants. It obtains information on alliances from public sources, including Securities and Exchange Commission filings, trade publications, and news/wire service reports. Stock returns were gathered from Center for Research in Security Prices (CRSP), and other firm information was gathered from COMPUSTAT.

\section{Firm and Alliance Sample}

The sample consisted of firms in the computer software industry (i.e., Standard Industrial Classification [SIC] codes
7372 and 7373) that announced alliances from 1988 to 2005. We drew the sample of firms from this industry for two reasons. First, the high-tech sector has been viewed historically as receiving less value from marketing (Workman 1993). Second, we wanted to examine our hypotheses within a single industry to limit extraneous sources of variance (Bass, Cattin, and Wittink 1978).

Following recent research (Lavie 2007), we took three steps to generate the firm sample. First, we identified all the public firms in SIC codes 7372 and 7373 that announced an alliance from 1988 to 2005. Second, to facilitate the calculation of network characteristics, we focused only on firms that had been in existence for five years preceding the alliance announcement. ${ }^{5}$ Using this criterion, the sample consisted of 273 firms. Third, to ensure that we could calculate abnormal returns, we cross-checked the firms in the CRSP database and found data available for 250 firms.

We took the following steps to generate our sample of alliances from these firms. First, we located 7566 alliances announced by these 250 firms. Second, we classified each alliance as marketing or nonmarketing by electronically coding the alliance description using a dictionary of marketing terms. Of all alliances, $80 \%$ could be classified using this approach. Two independent judges manually classified the remaining $20 \%$. Interjudge reliability was $90 \%$, and differences were resolved through discussion. Using this procedure, we identified 1135 marketing alliances. Third, to observe stock market outcomes, we constrained the sample to alliances for which complete data were available from the COMPUSTAT and CRSP databases. Furthermore, to calculate marketing resources, we needed data for the ten years preceding the alliance announcement. This resulted in a sample of 495 alliance announcements.

Fourth, we carefully inspected each announcement and eliminated those that involved alliance terminations or continuations of previously announced alliances. This left a sample of 378 marketing alliances. We then eliminated (1) alliances with no clearly identifiable announcement date, alliances with press announcements before the SDC announcement date, and alliance announcements that could not be cross-verified in another database $(n=15$ alliances lost) and (2) alliances that involved more than two partners (to ensure that we could account for partner characteristics in a uniform manner) ( $\mathrm{n}=63$ alliances lost). This resulted in 300 marketing alliances. Finally, we focused only on marketing alliances that involved a publicly traded partner because we wanted to control for partner characteristics that are only available for publicly traded firms. The resultant sample consisted of 230 marketing alliances involving 103 firms. We acknowledge that the imposed restrictions could result in selection biases. However, pragmatic considera-

\footnotetext{
${ }^{5}$ For example, for a marketing alliance announced in 1998, we constructed the network variables using alliances announced from 1992 to 1997 . Although there is variation in terms of the period used to define a network, some research uses either five or seven years for network measures (Gulati and Gargiulo 1999; Schilling and Phelps 2007). A sensitivity analyses indicates that our results do not change if we use alternative numbers of years.
} 
tions dictated the constraints that were imposed at various stages.

In terms of descriptive information about the sample of firms and partners, we observe the following: assets (millions of dollars): firm $(\mathrm{M}=\$ 21,762, \mathrm{SD}=\$ 32,186)$ versus partner $(\mathrm{M}=\$ 28,743, \mathrm{SD}=\$ 63,671)$; sales (millions of dollars): firm $(\mathrm{M}=\$ 16,900, \mathrm{SD}=\$ 26,515)$ versus partner $(\mathrm{M}=\$ 19,392, \mathrm{SD}=\$ 26,397)$; market capitalization (millions of dollars): firm $(\mathrm{M}=\$ 58,932, \mathrm{SD}=\$ 110,091)$ versus partner $(\mathrm{M}=\$ 40,679, \mathrm{SD}=\$ 70,729)$; total employees: firm $(\mathrm{M}=61,042, \mathrm{SD}=100,400)$ versus partner $(\mathrm{M}=59,769$, $\mathrm{SD}=87,566)$. These differences are not significant, except that firm market cap is greater than partner market cap. Given the market cap and asset profile of firms and partners, our sample can be characterized as midsized firms.

\section{Dependent Variable: Firm Abnormal Stock Returns}

Table 1 provides the descriptive statistics and correlations for our variables. Our dependent variable is the firm's abnormal stock returns. Using a standard event study method, we calculated firm abnormal returns using two approaches - the conventional market model and the FamaFrench model as modified by Carhart (1997).

Market model. To estimate the market model, we used daily data on the stock market returns of each firm from the CRSP database during a 240-day period ending ten days before the event day: $r_{i t}=\alpha_{i}+\beta_{i} r_{m t}+\varepsilon_{i t}$, where $r_{i t}$ denotes the daily returns for firm $i$ on day $t, r_{m t}$ is the daily returns on the equally weighted index (constituting all stocks listed in CRSP), $\alpha_{i}$ and $\beta_{i}$ are firm-specific parameters, and $\varepsilon_{i t}$ is distributed i.i.d. normal (Brown and Warner 1985). We then used the estimates obtained from this model to predict the daily returns for each firm for the event day, $\hat{r}_{i t}=\hat{\alpha}_{i}+\hat{\beta}_{i} r_{m t}$, where $\hat{r}_{i t}$ is the predicted daily return and $\hat{\alpha}_{i}$ and $\hat{\beta}_{i}$ are the model estimates. Thus, we calculated daily firm-specific abnormal returns $\left(\mathrm{AR}_{\mathrm{it}}\right)$ for firm $\mathrm{i}$ at time $\mathrm{t}$ as $\mathrm{AR}_{\mathrm{it}}=\mathrm{r}_{\mathrm{it}}-\hat{\mathrm{r}}_{\mathrm{it}}$. The cumulative abnormal returns for the event period ranging from $t_{1}$ to $t_{2}$ is $\mathrm{CAR}_{\mathrm{i}}\left[\mathrm{t}_{1}, \mathrm{t}_{2}\right]=\Sigma_{\mathrm{t}=\mathrm{t}_{1}}^{\mathrm{t}_{2}} \mathrm{AR}_{\mathrm{it}}$. The cumulative average abnormal return over various event windows beginning with $t_{1}$ and ending in $t_{2}$ is $\mathrm{CAAR}_{\mathrm{t}_{1}, \mathrm{t}_{2}}=\Sigma_{\mathrm{i}=1}^{\mathrm{N}}$ $\mathrm{CAR}\left[\mathrm{t}_{1}, \mathrm{t}_{2}\right] / \mathrm{N}$.

The chosen event window should be long enough to account for dissemination of information regarding the alliance announcement over time. To avoid leakage concerns and to ensure that our event dates are accurate, we followed a two-step procedure. First, we performed a manual verification of press announcement as discussed previously. Second, following other research (Agrawal and Kamakura 1995; Geyskens, Gielens, and Dekimpe 2002), we calculated the cumulative average abnormal returns for various windows ( +10 days to -10 days) and tested the significance of various event windows using the t-statistic described by Brown and Warner (1985). Consistent with Geyskens, Gielens, and Dekimpe (2002), we selected the event window with the most significant t-statistic, day -2 to day +1 .

Fama-French model. The Fama-French model has gained prominence because of its ability to explain stock market movements (Fama and French 1993, 1996). As modified by Carhart (1997), the four-factor model builds on the previously described market model and includes three additional factors to explain the excess returns $r_{i t}$, as follows:

$$
r_{i t}=\alpha_{i}+\beta_{i} r_{m t}+s_{i} S M B B_{t}+h_{i} H_{M L}+u_{i} U M D D_{t}+\varepsilon_{i, t},
$$

where, in addition to the return on the overall market index (CRSP value-weighted NYSE/AMEX/NASDAQ index), $\mathrm{SMB}_{\mathrm{t}}$ is the return differential between portfolios of small and large market capitalization stocks, $\mathrm{HML}_{\mathrm{t}}$ is the differential between portfolios of high- (value) and low- (growth) book-to-market ratio stocks, and $\mathrm{UMD}_{\mathrm{t}}$ is the differential between portfolios of high- and low-prior-return stocks. As in the market model, we used the estimates obtained from this model to predict the daily returns for each firm for the event day. Using the actual $\left(\mathrm{r}_{\mathrm{it}}\right)$ and estimated $\left(\hat{\mathrm{r}}_{\mathrm{it}}\right)$ daily returns, we calculated firm-specific daily abnormal returns as $A R_{i t}=r_{i t}-\hat{r}_{i t}$, where $A R_{i t}$ are the daily firm-specific abnormal returns. Firm-specific cumulative abnormal returns, $\mathrm{CAR}_{\mathrm{it}}$, pertain to the firm's abnormal returns aggregated across the event window.

Role of networks. Our tests are premised on the idea that information about a firm's network of relationships plays a role in investor reactions to a firm's announcement of a new alliance. What evidence do we have for this view? First, many analysts are assigned to investigate particular firms and thus accumulate a great deal of information about the firms' partnerships over time. This information is available in press releases and in each firm's own public documents, such as $10-\mathrm{K}$ reports. ${ }^{6}$ Thus, it is reasonable to conclude

\footnotetext{
${ }^{6}$ To gauge the information available to analysts, we took the following steps: First, for a sample of the top ten software firms on The Software 500 (IBM, Microsoft, EDS, Hewlett-Packard, Accenture, Computer Sciences Corporation, Oracle, SAP, Capgemini, and Hitachi), we searched their 2007 annual reports for the words "alliance," "partnership," and "network." We eliminated references to the term "network" when it referred to nonpartnership-based networks, such as Microsoft's Real Network. The average frequency of these terms was as follows: alliance $(\mathrm{M}=6.7, \mathrm{SD}=6.6)$, partnership $(\mathrm{M}=4.3, \mathrm{SD}=3.3)$, and network $(\mathrm{M}=7.1, \mathrm{SD}=11.1)$. In many cases, the annual reports for the software companies make bold statements about the firm's networks, alliances, and partnerships. For example, SAP's annual report refers to "The SAP Ecosystem: A Worldwide Network of Innovation" that is built from "a diverse network of partners, developers, business experts, and users." Likewise, IBM reports "Alliance Investments" and "Strategic Alliances" listed as "Intangible Assets." Second, we performed a search in Proquest Newspapers for the top ten firms in The Software 500 for the articles with the name of the company in the title or abstract and the word "partnership" or "alliance" in the text for the last 12 months. We did not include reference to the term "network" because this would have produced hundreds of articles referring to computer networks, not business networks. We also eliminated the count for Microsoft, which during this year was in negotiations with Yahoo, thus producing a large number of articles on this partnership (i.e., approximately $75 \%$ of the 356 qualifying newspaper articles about Microsoft involve the Yahoo merger). With these rules, we observed that in the last year alone, the articles referencing partnerships or alliances per firm were reasonably high $(\mathrm{M}=13.2$, $\mathrm{SD}=9.6$ )
} 
TABLE 1

Descriptive Information and Intercorrelations

\begin{tabular}{|c|c|c|c|c|c|c|c|c|c|c|c|c|c|c|c|c|c|c|c|c|}
\hline Variable & M & SD & 1 & 2 & 3 & 4 & 5 & 6 & 7 & 8 & 9 & 10 & 11 & 12 & 13 & 14 & 15 & 16 & 17 & 18 \\
\hline 1. Firm abnormal returns (Fama-French) & .014 & .057 & 1.000 & & & & & & & & & & & & & & & & & \\
\hline 2. Firm network centrality & 82.32 & 104.920 & -.037 & 1.000 & & & & & & & & & & & & & & & & \\
\hline 3. Firm network efficiency & .033 & .176 & .441 & -.064 & 1.000 & & & & & & & & & & & & & & & \\
\hline 4. Firm network density & .440 & .520 & .364 & .110 & .293 & 1.000 & & & & & & & & & & & & & & \\
\hline 5. Firm network reputation & .046 & .576 & -.066 & -.001 & .011 & -.111 & 1.000 & & & & & & & & & & & & & \\
\hline 6. Firm marketing alliance capability & .001 & .040 & .157 & -.004 & .009 & .063 & -.026 & 1.000 & & & & & & & & & & & & \\
\hline 7. Firm alliance experience (in hundreds) & 1.792 & 5.77 & -.060 & .395 & -.071 & -.059 & -.064 & .017 & 1.000 & & & & & & & & & & & \\
\hline 8. Firm marketing resources & .596 & 2.434 & -.110 & .533 & -.104 & -.080 & .468 & .034 & .229 & 1.000 & & & & & & & & & & \\
\hline 9. Change in firm network density & -.011 & .186 & -.086 & .067 & .035 & .078 & .018 & -.031 & .018 & -.021 & 1.000 & & & & & & & & & \\
\hline 10. Change in firm network efficiency & .000 & .003 & -.047 & -.018 & -.028 & .004 & -.027 & -.003 & -.007 & -.030 & .332 & 1.00 & & & & & & & & \\
\hline 11. Change in firm network reputation & -.005 & .007 & -.053 & -.066 & .055 & -.094 & -.042 & -.190 & -.100 & -.102 & -.032 & .002 & 1.000 & & & & & & & \\
\hline 12. Partner network centrality & 51.732 & 50.199 & .004 & -.059 & .061 & -.044 & .067 & -.180 & -.073 & -.026 & -.010 & .000 & -.170 & 1.000 & & & & & & \\
\hline 13. Partner network efficiency & .079 & .168 & .041 & -.232 & .019 & .079 & .126 & -.037 & -.123 & -.126 & .023 & -.006 & -.070 & .198 & 1.000 & & & & & \\
\hline 14. Partner network density & .452 & .499 & -.087 & .087 & -.048 & -.093 & -.027 & -.031 & .210 & .241 & .059 & -.024 & -.101 & -.034 & .272 & 1.000 & & & & \\
\hline 15. Partner network reputation & .340 & .320 & .064 & .178 & .033 & .029 & .008 & -.015 & .086 & -.017 & .064 & -.013 & -.106 & .697 & .191 & .073 & 1.000 & & & \\
\hline 16. Partner marketing alliance capability & -.002 & .016 & -.197 & -.008 & -.155 & -.147 & -.005 & .012 & .002 & .018 & -.044 & .014 & .044 & .044 & -.062 & -.043 & .028 & 1.000 & & \\
\hline 17. Partner marketing resources & .269 & 1.360 & -.053 & .203 & -.102 & -.047 & -.030 & .021 & .307 & .229 & -.013 & .000 & -.046 & -.046 & -.083 & .131 & -.029 & -.008 & 1.000 & \\
\hline 18. Relative size of alliance partners & .126 & .695 & .0001 & .080 & .005 & -.043 & .219 & .006 & -.020 & .234 & .000 & -.014 & .022 & -.044 & -.050 & .012 & -.032 & -.121 & -.016 & 1.00 \\
\hline
\end{tabular}


that investors do not need network-level information about the firm to form impressions about the firm's network. Instead, over time, the analyst will be exposed to information about the firm's alliances and then form an aggregatelevel impression about the network characteristics.

Second, conversations with the head of sales for SDC indicated that investment firms and banks are a large number of its clients. Thus, gathering alliance information is easy and can be done at a low cost. Third, industry (e.g., Standard \& Poor's; see http://www.softwaremag.com/) and government (e.g., Department of Justice, Securities and Exchange Commission) sources regularly collect information about industry licensing, alliances, mergers, and acquisitions for both competitive and legal reasons. Finally, there is evidence that investors examine the firm's network of partners during important firm events, such an initial public offerings (Cook, Kieschnick, and Van Ness 2006).

\section{Measures of Key Independent Variables}

Firm network centrality. We operationalized network centrality as degree centrality. We measured firm degree centrality by the number of partners directly connected to a firm (Freeman 1979; Scott 1991). Consistent with this, we measured firm degree centrality as the number of direct firm partners in the five years preceding the alliance announcement year. We used all alliances in the firm's network to create this and the other network measures.

Firm network efficiency. Consistent with previous research (Baum, Calabrese, and Silverman 2000), we measured network efficiency by the number of firm partners in nonoverlapping SIC codes in the five years preceding the year of alliance announcement. The measure is a variation of the Hirschman-Herfindahl index. Specifically, a firm's network efficiency is as follows:

$$
\text { Network Efficiency }{ }_{i}=\left[1-\sum_{\mathrm{ij}}\left(\operatorname{PropAll}_{\mathrm{ij}}\right)^{2}\right] / \mathrm{TA}_{\mathrm{i}},
$$

where PropAll $\mathrm{ij}_{\mathrm{j}}$ is the proportion of all firm i's alliances that are in SIC code $\mathrm{j}$ and $\mathrm{TA}_{\mathrm{i}}$ is the total number of alliances. For example, a firm with a total of six alliances, two of which appear in each of three different SIC codes, will have a network efficiency score of $\left[1-(2 / 6)^{2}+(2 / 6)^{2}+(2 / 6)^{2}\right] /$ $6=.111$, whereas a firm with a total of six alliances, five of which are in one SIC code and one of which is in another SIC code, will have a network efficiency calculation of [1 $\left.(5 / 6)^{2}+(1 / 6)^{2}\right] / 6=.046$.

Firm network density. Our measure focuses on local network density rather than on global density because ties between firms in distant regions of the network are less likely to affect the firm learning and performance. To capture the firm's local network density, we analyzed the matrix of ties among the firm's direct partners. Our measure of local density is the total number of unique relationships between a firm's partners divided by the total number of possible ties among its partners if each partner were tied to every other partner (Rowley, Behrens, and Krackhardt 2000).

Firm network reputation. We measured network reputation using an approach consistent with Houston and John- son (2000) and Kalaignanam, Shankar, and Varadarajan (2007). Specifically, we assessed the reputation of each partner firm in the firm's network using Fortune's reputation survey. If a partner was listed among the top Fortune 100 firms, we gave it a value of 1; if not, we gave it a value of 0 . We then averaged the reputation scores across all partners within a firm's prior network of alliances. Thus, the final measure ranged from 0 to $1 .^{7}$

Firm marketing alliance capability. Our measure uses the trend in the firm's ability to generate abnormal returns from alliances over time. To calculate, we first determined the average abnormal returns accruing to all firm marketing alliances in a year and the previous year, as well as the difference in average abnormal return $(\triangle \mathrm{AAR})$. We calculated $\triangle \mathrm{AAR}$ for the ten-year period preceding the alliance announcement. We then used an exponential smoothing model and calculated the trend or smoothed average for this series, such that recent $\triangle \mathrm{AARs}$ are weighted more than previous $\triangle$ AARs. This smoothed average is our measure of alliance capability for a given firm/year.

\section{Control Variables}

The value created by a marketing alliance should be influenced by firm marketing resources. Likewise, firms may rely on external partners to overcome a deficiency of marketing resources (Swaminathan, Murshed, and Hulland 2008). If so, partner marketing resources should affect the firm's abnormal returns from the announced alliance. To measure the firm or partner marketing resources, we followed Dutta, Narasimhan, and Rajiv (1999) and used four indicators: (1) the installed base of customers (i.e., firm sales), (2) firm resources devoted to building customer relationships (i.e., firm receivables), (3) marketing expenditures (i.e., firm selling, general, and administrative expenses), and (4) firm advertising expenditures. Dutta, Narasimhan, and Rajiv also include a firm's base of technical know-how because it represents the stock of technical know-how that might be converted to products or processes and sold to customers. We use research-and-development expenditures as an indicator of a firm's base of technical know-how because it is more relevant in the software industry.

Following Dutta, Narasimhan, and Rajiv (1999), we obtained these five measures for the firm or partner for the ten years preceding the alliance announcement. Data were weighted using a Koyck lag function. For example, $\operatorname{ADSTOCK}=\sum_{\mathrm{k}=1}^{\mathrm{k}=\mathrm{t}} \delta^{\mathrm{t}-\mathrm{k}} \int \times \operatorname{ADEXPENSE}_{\mathrm{k}}$, where $\mathrm{t}=1$, $2, \ldots, 10$ years. We empirically determined a smoothing constant, used to minimize prediction errors, by testing different weights. Because the resources are highly correlated, introducing these measures into the model independently

\footnotetext{
${ }^{7}$ Although we could have used the reputation score Fortune gives to each firm on the list, given the small number of firms included on the list relative to the large number of partners in our firm's networks, 0/1 appears to be a more valid indicator. Specifically, for the period used in our research, Fortune selected firms with the highest reputation scores within their industries to include. Given this, we concluded that the mere presence of a firm on the list signals its excellent reputation within its industry, and we used a dummy variable to capture whether a firm was on the list.
} 
may create multicollinearity. For this reason, we combined these resources through a principal components analysis to form an index of firm marketing resources.

Alliance experience contributes to value creation from alliances (Anand and Khanna 2000; Kalaignanam, Shankar, and Varadarajan 2007). We measured firm alliance experience by calculating the total number of alliances announced by a firm (both marketing and nonmarketing alliances) in the ten years preceding the announcement.

To correct for the size of alliance partners, we measured the relative size of alliance partners as the ratio of market capitalization of the firm to the partner (Moeller, Schlingemann, and Stulz 2004). We measured market capitalization by multiplying the number of shares and the share prices at the end of the year. Subsequently, we demonstrate that our results are robust to other measures.

Following previous research on alliances (e.g., Rindfleisch and Moorman 2001), we classified intraindustry alliances as horizontal (20\%) and interindustry alliances as vertical $(80 \%)$. The dummy variable had a value of 1 for horizontal alliances and 0 for vertical alliances. Some marketing alliances also have a product development objective, which we coded unambiguously using the SDC announcement. The dummy variable was 1 if the alliance had both product development and marketing objectives (26\%) and 0 if the alliance had only marketing objectives.

Repeat partnering between firms increases trust (Goerzen 2007; Wuyts, Stremersch, and Dutta 2004). We collected repeat partnering information from the SDC database and controlled for it with a dummy variable. Approximately $5 \%$ of alliances were repeat partnerships between the firm and the partner.

The value of a new alliance can vary depending on how the new partner's characteristics change the firm's network characteristics. For example, if the new alliance involves a partner in an industry in which the firm already has an alliance, this will reduce firm network efficiency, or if the partner has a high reputation, this will raise the reputation of the firm's network. Note that these are not measures of the partner's network, which we consider next. Instead, they are measures of how the partner's characteristics change the firm's network. 8

Partner network characteristics can also influence firm value from a marketing alliance (Lavie 2007). We calculated partner network centrality, density, efficiency, reputation, and marketing alliance capability using procedures identical for the firm.

\section{Partner Selection Model Development and Estimation}

Networks can act as a referral resource that helps firms identify good alliance partners. Thus, to correctly estimate the impact of networks on the value created from the new

${ }^{8}$ We did not include change in network centrality because network centrality refers to the number of unique partners a firm is connected to in its network. Thus, if network centrality increases as a function of the alliance, this means that the new alliance is with a new partner. Therefore, the change in network centrality is the same as the repeat partnering control variable. alliance, it is necessary to control for the potential bias inherent in the selection process. The selection model accounts for heterogeneity due to firm and time effects through a random-effects model. Our final model uses a random-effects simultaneous model estimation procedure involving the selection model and the value creation model (Verbeek and Nijman 1992). Appendix A summarizes our selection model procedures and results.

\section{Value Creation Model Development and Estimation}

We model the impact of predictor variables on abnormal stock returns accruing to firm $i$ as a consequence of an alliance $\mathrm{k}$ involving a firm $\mathrm{i}$ and partner $\mathrm{p}$ announced at time $\mathrm{t}$ as follows:

$$
\begin{aligned}
& \text { Abnormal Stock Returns } \mathrm{s}_{\mathrm{ikt}} \\
& \left.=\beta_{0}+\beta_{1} \text { (Relative Size of Firm and Partner }\right)_{\mathrm{k}} \\
& +\beta_{2}(\text { Horizontal Alliance })_{\mathrm{k}}+\beta_{3}(\text { Repeat Partnering })_{\mathrm{k}} \\
& +\beta_{4} \text { (Marketing Alliance with Product Development } \\
& \text { Component })_{\mathrm{k}}+\beta_{5}(\text { Firm Network Centrality })_{\text {it }} \\
& +\beta_{6}(\text { Firm Network Efficiency })_{\text {it }} \\
& +\beta_{7}\left(\text { Firm Network Efficiency }^{2}\right)_{\text {it }} \\
& +\beta_{8}(\text { Firm Network Density })_{\text {it }} \\
& +\beta_{9}(\text { Firm Network Density } 2)_{\text {it }} \\
& +\beta_{10}(\text { Firm Network Reputation })_{\text {it }} \\
& +\beta_{11}(\text { Firm Marketing Alliance Capability })_{\text {it }} \\
& +\beta_{12}(\text { Firm Marketing Resources })_{\text {it }} \\
& +\beta_{13}(\text { Firm Alliance Experience })_{i t} \\
& +\beta_{14}(\Delta \text { Firm Network Efficiency })_{\text {it }} \\
& +\beta_{15}(\Delta \text { Firm Network Density })_{\text {it }} \\
& +\beta_{16}(\Delta \text { Firm Network Reputation })_{\text {it }} \\
& +\beta_{17}(\text { Partner Network Centrality })_{\mathrm{pt}} \\
& +\beta_{18}(\text { Partner Network Efficiency })_{\mathrm{pt}} \\
& +\beta_{19}\left(\text { Partner Network Efficiency }{ }^{2}\right)_{\mathrm{pt}} \\
& +\beta_{20}(\text { Partner Network Density })_{\mathrm{pt}} \\
& +\beta_{21}\left(\text { Partner Network Density }{ }^{2}\right)_{\mathrm{pt}} \\
& +\beta_{22}(\text { Partner Network Reputation })_{\mathrm{pt}} \\
& +\beta_{23}(\text { Partner Marketing Alliance Capability })_{\mathrm{pt}} \\
& +\beta_{24}(\text { Partner Marketing Resources })_{\mathrm{pt}} \\
& +\beta_{25}(\text { Selectivity Parameter })_{\mathrm{pt}}+\mathrm{v}_{\mathrm{it}} \text {. }
\end{aligned}
$$

Alliance characteristics pertain to a given alliance $\mathrm{k}$, whereas firm, network, and change in network characteristics pertain to a given firm $i$ at time t. Partner characteristics are specific to partner $\mathrm{p}$ at time $\mathrm{t}$. The error term $\mathrm{v}_{\mathrm{it}}$ consists of three components and can be represented as $\mathrm{v}(\mathrm{i}, \mathrm{t})=$ $x(i, t)+y(i)+z(t)$, where $y(i)$ represents the firm effect, $z(t)$ represents the time effect, and $\mathrm{x}(\mathrm{i}, \mathrm{t})$ represents the remain- 
ing error, respectively. We mean-centered the measures used in this model before forming quadratic terms to ease interpretation.

Finally, given that the sample consists of multiple alliance announcements by firms across multiple years, we require a method that minimizes potential bias due to firmspecific and time-varying effects. According to the results of the Hausman test, a random-effects specification is more appropriate than a fixed-effects model $\left(\chi^{2}(25)=21.31\right.$, not significant [n.s.]). Furthermore, testing for heteroskedasticity and autocorrelation indicated no problems (Drukker 2003; Wooldridge 2002).

\section{Results}

\section{Do Marketing Alliance Announcements Increase Firm Abnormal Returns?}

Consistent with standard practice, we first test whether the cumulative abnormal returns over various event windows are different from zero. The results from both a t-test (Brown and Warner 1985) and a two-tailed generalized sign Z-test statistic suggest that cumulative abnormal returns in the event window period are positive and significantly different from zero (see Table 2). If we focus on the -2-day to +1 -day event window, the results indicate that a marketing alliance announcement increases stock returns $1.4 \%$ for the software firm $(\mathrm{t}=2.98, p<.01)$. These results support $\mathrm{H}_{1}$. Table 2 demonstrates that this finding is also robust across event windows. Figure 2 depicts the daily returns for the -10- to +10-day event window (e.g., Tellis and Johnson 2007).

\section{Does a Firm's Network Affect the Abnormal Returns from a Marketing Alliance Announcement?}

Recall that these value creation models are estimated simultaneously with the selection model (for results, see Appen$\operatorname{dix}$ A). The selectivity parameter in Table 3 accounts for the selection bias and is produced as a consequence of the simultaneous estimation of the selection and value creation models.
FIGURE 2

Average Abnormal Returns Before and After a Marketing Alliance Announcement

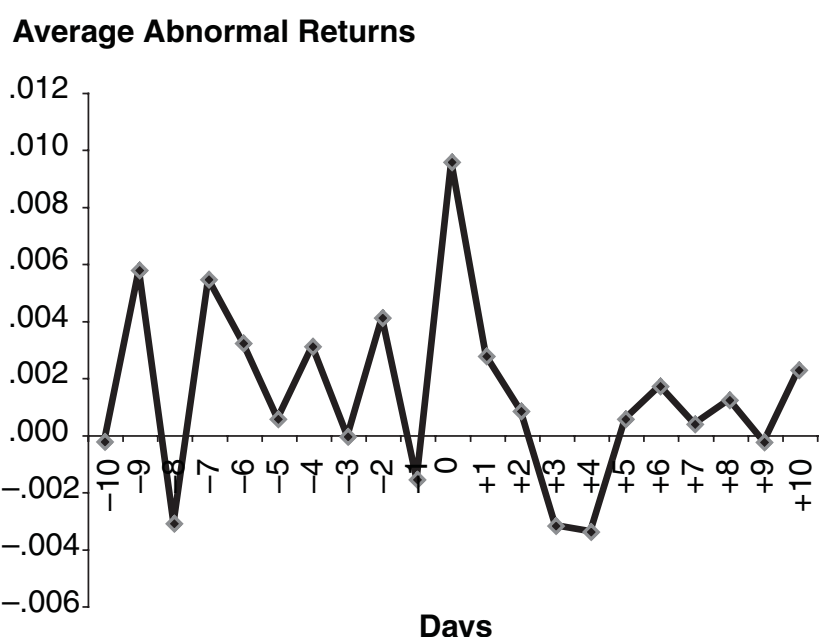

Notes: This figure presents the daily firm abnormal returns before and after the alliance announcement. Day 0 corresponds to the event day (i.e., day on which marketing alliance was announced).

Recall that the error term $v_{i t}$ in the value creation equation for abnormal stock returns consists of three components - the firm effect, the time effect, and the remaining error. Both firm and time effects are significant, and the variance components for the firm, time, and remaining errors are $.0002\left(\sigma_{\mathrm{y}}^{2}\right)$, .0001 $\left(\sigma_{\mathrm{z}}^{2}\right)$, and .001 $\left(\sigma_{\mathrm{x}}^{2}\right)$, respectively; the proportion of the total variance contributed by the panel-level (firm and time effects) variance component in the model is $45 \%$.

We estimate two models to test $\mathrm{H}_{2}-\mathrm{H}_{6}$ (see Table 3 ). Model 1 uses the Fama-French four-factor benchmark. Model 2 is based on the market model and uses an equally weighted benchmark portfolio consisting of CRSP stocks. Both models use the same event window as mentioned previously (day -2 to day +1 ). The results associated with our

TABLE 2

Cumulative Abnormal Returns Across Various Event Windows

\begin{tabular}{|c|c|c|c|c|c|c|c|c|}
\hline \multirow[b]{2}{*}{$\begin{array}{l}\text { Event } \\
\text { Window }\end{array}$} & \multicolumn{4}{|c|}{ Fama-French Four-Factor Model } & \multicolumn{4}{|c|}{ Market Model (Equally Weighted) } \\
\hline & M & SD & t-Value & $\begin{array}{l}\text { Generalized } \\
\text { Sign Z }\end{array}$ & M & SD & t-Value & $\begin{array}{c}\text { Generalized } \\
\text { Sign Z }\end{array}$ \\
\hline-3 to +3 days & .012 & .083 & 1.56 & $2.18^{\star}$ & .011 & .080 & $1.64^{\star}$ & $2.05^{\star}$ \\
\hline-2 to +2 days & .016 & .068 & $2.41^{* *}$ & $3.10^{\star *}$ & .015 & .069 & $2.53^{\star \star}$ & $4.02^{\star \star \star}$ \\
\hline-1 to +1 days & .011 & .049 & $2.38^{\star \star}$ & $3.89^{\star \star \star}$ & .011 & .051 & $2.33^{\star \star}$ & $4.55^{\star \star \star}$ \\
\hline-1 to 0 days & .008 & .042 & $2.02^{*}$ & $3.23^{\star \star}$ & .008 & .044 & $2.06^{\star \star}$ & $3.50^{\star \star \star}$ \\
\hline 0 to +1 days & .012 & .061 & $2.69^{\star \star}$ & $3.76^{\star \star}$ & .013 & .043 & $2.63^{\star \star}$ & $4.42^{\star \star \star}$ \\
\hline-1 to +2 days & .012 & .072 & $1.64^{*}$ & $3.23^{\star \star}$ & .012 & .064 & $1.91^{\star}$ & $4.56^{\star \star \star}$ \\
\hline-2 to +1 days & .014 & .057 & $2.98^{\star \star}$ & $2.97^{\star \star}$ & .014 & .058 & $2.96^{\star \star}$ & $4.42^{\star \star \star}$ \\
\hline
\end{tabular}


TABLE 3

Value Creation Model Results

\begin{tabular}{|c|c|c|c|c|}
\hline \multirow[b]{2}{*}{ Intercept } & \multicolumn{2}{|c|}{$\begin{array}{l}\text { Model 1: Fama-French Four-Factor } \\
\text { Model (Event Day }-2 \text { to }+1)\end{array}$} & \multicolumn{2}{|c|}{$\begin{array}{l}\text { Model 2: Market Model Equally } \\
\text { Weighted (Event Day }-2 \text { to }+1 \text { ) }\end{array}$} \\
\hline & .0243 & $(.0131)^{\dagger}$ & .01703 & $(.01095)$ \\
\hline \multicolumn{5}{|l|}{ Alliance Characteristics } \\
\hline $\begin{array}{l}\text { Relative size of partners } \\
\text { Horizontal alliance } \\
\text { Repeat partnership } \\
\text { Marketing alliance with product development }\end{array}$ & $\begin{array}{r}.00001 \\
.00968 \\
-.00398 \\
.00094\end{array}$ & $\begin{array}{l}(.00005) \\
(.00974) \\
(.01513) \\
(.00849)\end{array}$ & $\begin{array}{r}-.00002 \\
.01998 \\
-.01022 \\
-.00473\end{array}$ & $\begin{array}{l}(.00004) \\
(.00813)^{\star \star} \\
(.01263) \\
(.0071)\end{array}$ \\
\hline $\begin{array}{l}\text { Firm Characteristics } \\
\text { Network centrality } \\
\text { Network efficiency } \\
\text { Network efficiency² } \\
\text { Network density } \\
\text { Network density² } \\
\text { Network reputation } \\
\text { Marketing alliance capability } \\
\text { Alliance experience } \\
\text { Marketing resources } \\
\text { Change in network efficiency } \\
\text { Change in network density } \\
\text { Change in network reputation }\end{array}$ & $\begin{array}{l}.0003 \\
.10344 \\
-.18213 \\
.02843 \\
-.05723 \\
-.00194 \\
.22486 \\
-.00002 \\
.00066 \\
-.39874 \\
-.00893 \\
-.0002\end{array}$ & $\begin{array}{l}(.00049) \\
(.01876)^{\star \star \star} \\
(.04018)^{\star \star \star} \\
(.01019)^{\star \star \star} \\
(.01251)^{\star \star} \\
(.00535) \\
(.0749)^{\star \star \star} \\
(.00006) \\
(.00799) \\
(1.1797) \\
(.01609) \\
(.00038)\end{array}$ & $\begin{array}{c}.00052 \\
.06456 \\
-.12049 \\
.03532 \\
-.0232 \\
.00708 \\
.21866 \\
-.00001 \\
.00095 \\
-.3154 \\
.00789 \\
.00014\end{array}$ & $\begin{array}{l}(.00041) \\
(.01566)^{\star \star \star} \\
(.03353)^{\star \star \star} \\
(.0102)^{\star \star \star} \\
(.01167)^{\star} \\
(.00447) \\
(.06244)^{\star \star \star} \\
(.00005) \\
(.00669) \\
(.08841) \\
(.01344) \\
(.00031)\end{array}$ \\
\hline $\begin{array}{l}\text { Partner Characteristics } \\
\text { Network centrality } \\
\text { Network efficiency } \\
\text { Network efficiency² } \\
\text { Network density } \\
\text { Network density² } \\
\text { Network reputation } \\
\text { Marketing alliance capability } \\
\text { Marketing resources }\end{array}$ & $\begin{array}{r}-.00027 \\
-.00917 \\
.00354 \\
.03627 \\
-.02329 \\
-.00283 \\
-.4805 \\
.00726\end{array}$ & $\begin{array}{l}(.00063) \\
(.01725) \\
(.01127) \\
(.05249) \\
(.06452) \\
(.00763) \\
(.17808)^{\star \star \star} \\
(.00827)\end{array}$ & $\begin{array}{r}-.00017 \\
-.0083 \\
.00132 \\
.01006 \\
-.00466 \\
.01517 \\
-.46278 \\
-.00069\end{array}$ & $\begin{array}{l}(.00052) \\
(.0144) \\
(.00941) \\
(.04384) \\
(.05389) \\
(.0069)^{\star \star} \\
(.14866)^{\star \star \star} \\
(.00186)\end{array}$ \\
\hline \multicolumn{5}{|l|}{ Selectivity Parameter } \\
\hline $\begin{array}{l}\text { R-square } \\
\text { Log-likelihood } \chi^{2}(\text { d.f. }=25)\end{array}$ & $\begin{aligned} 35 & -1 \\
166 . & -\end{aligned}$ & $\begin{array}{l}9 \% \\
76^{\star \star \star}\end{array}$ & & $\begin{array}{l}\% \\
5^{\star * \star}\end{array}$ \\
\hline
\end{tabular}

hypotheses are robust across these models. Given this, we discuss only the Fama-French four-factor results.

The overall model is significant (log-likelihood ratio $\left.\chi^{2}=166.76, p<.001\right)$, and the $\mathrm{R}$-square is reasonable (39\%). Considering the hypothesized firm network characteristics, the effect of network centrality on abnormal returns from the marketing alliance is not significant $(\beta=$ .00030 , n.s.). Thus, $\mathrm{H}_{2}$ is not supported. The results indicate a positive and significant main effect $(\beta=.10344, p<.001)$ and a negative and significant quadratic effect $(\beta=-.18213$, $p<.001)$ for network efficiency on firm abnormal returns. These results support $\mathrm{H}_{3}$. The results likewise indicate a positive and significant main effect $(\beta=.02843, p<.01)$ and a negative and significant quadratic effect $(\beta=-.05723$, $p<.01)$ for network density on firm returns. These results support $\mathrm{H}_{4}$. The results show that network reputation has no effect ( $\beta=-.00194$, n.s.), failing to support $\mathrm{H}_{5}$. Finally, the results show that a firm's marketing alliance capability has a positive and significant effect on abnormal returns $(\beta=$ $.22486, p<.001)$. This result supports $\mathrm{H}_{6}$.

To determine the inflection point associated with the nonlinear effects of network efficiency and network density, we calculate the first partial derivative of the regression equation with respect to the network efficiency and network density variables. We identify the inflection point (when the curve slopes downward), which corresponds to the point at which the regression of abnormal returns on network efficiency and density is zero at the maximum predicted value of abnormal returns. Accordingly, the inflection point for network efficiency is .25 . At this point, returns from network efficiency begin to diminish. Note that the inflection point is higher than the mean for this sample. Still, given that network efficiency ranges from 0 to 1 , the inflection point falls in the moderate range. The inflection point for 
network density is .60. Up to this point, density increases the value created from the announced alliance. After that point, increases in density produce diminishing returns.

Considering the other variables in the model, we find that neither changes in the firm's network characteristics (as a consequence of the alliance announcement) nor a firm's own marketing resources $(\beta=.00066$, n.s.) affect firm abnormal stock returns. In terms of partner characteristics, partner network centrality, efficiency, density, and reputation are not significant. Similarly, partner marketing resources are not significant. Notably, only partner marketing alliance capability is negative and significant $(\beta=$ $-.48050, p<.001)$. Finally, none of the four alliance-level variables were significant (see Table 3 ).

The results for the market model are similar to the Fama-French model with two exceptions: The impact of horizontal alliance is significant $(\beta=.01998, p<.01)$, and the impact of partner network reputation is significant $(\beta=$ $.01517, p<.01)$. Taken together, the results provide support for $\mathrm{H}_{1}, \mathrm{H}_{3}, \mathrm{H}_{4}$, and $\mathrm{H}_{6}$ but not for $\mathrm{H}_{2}$ and $\mathrm{H}_{5}$. We extensively tested the value creation model for robustness (for details, see Appendix B).

\section{Discussion}

\section{Contributions to Strategic Alliance Research}

Our contributions to strategic alliance research are threefold. First, prior research on the impact of marketing alliances on firm value has found mixed results: Kalaignanam, Shankar, and Varadarajan (2007) observe a positive effect, and Das, Sen, and Sengupta (1998) and Koh and Venkatraman (1991) observe a null effect. Our findings indicate a positive effect for marketing alliance announcements on abnormal returns in the computer software industry.

One reason for the observed differences is that the studies uncovering a null effect use a wider range of industries. We focus on software, whereas Kalaignanam, Shankar, and Varadarajan (2007) focus on information technology and telecommunications - both technology industries. Given differences in the value of networks across industries, a positive effect may have been present in the prior studies but obscured by sample variability. However, even in our pooled sample of both firms and their partners, which has a higher level of sample heterogeneity, we continue to observe a significant, positive effect for marketing alliances.

Given this, another and more persuasive reason for the difference is that the two studies involving null effects both focus on earlier periods (1972-1986 in Koh and Venkatraman [1991] and 1987-1991 in Das, Sen, and Sengupta [1998]). In contrast, Kalaignanam, Shankar, and Varadarajan (2007) focus on alliances announced in the 1993-2004 period, and we focus on alliances announced between 1988 and 2005. We speculate that during the earlier period, investors viewed marketing alliances as a strategic tool for firms in mature industries. Therefore, a marketing alliance announcement was viewed as a signal of a firm's low growth prospects within existing markets. Furthermore, new market entry is risky. If viewed solely as vehicles for market access, marketing alliances would be historically undervalued and thus might be contributing to the null effects in prior research. Since that time, a deeper appreciation of the role of marketing in growth industries has developed (e.g., Mizik and Jacobson 2003). Theory has advanced to clarify the role of alliances in providing firms with access to knowledge, resources, and reputation.

A second contribution to alliance research is our demonstration that network characteristics influence value creation from the announcement of a new marketing alliance. This finding extends prior alliance research, which has only indirectly captured the role of networks on firm value by focusing on the effect of firm alliance experience and capabilities. Our research offers a portrait of the independent effects of firm alliance and network factors. When including both firm alliance and network factors, we find that firm alliance experience (measured as the number of alliances announced by the firm) has no effect. This extends prior research, which has observed a positive effect (e.g., Kalaignanam, Shankar, and Varadarajan 2007).

A third contribution is our finding involving the positive effect of a firm's alliance capability. The results indicate that the stock market rewards the firm announcing the new alliance for a track record of successfully managing networks of alliances over time. At the same time, the firm's returns are weakened when it allies with a partner that has a similar successful track record. These results indicate that the stock market uses this information as a signal of how much the firm will benefit relative to partners (Khanna, Gulati, and Nohria 1998). This signal may be particularly valuable in network markets (Frels, Shervani, and Srivastava 2003), such as the software industry studied here. In these markets, a strong network can be integral to the success of new products and allow a firm to erect barriers to entry. Further research should examine this winner versus loser finding of alliance capability in other network industries.

Our research did not examine all the structural, relational, and legal factors that might influence how alliances operate. Further research should examine whether these factors moderate our findings. We also did not examine how marketing alliance type, such as brand, sales force, or joint promotion, influences firm value. Further research could also examine how structural and relational factors interact with various marketing alliance types to influence alliance outcomes (see Shah and Swaminathan 2008).

\section{Contributions to Networks Research}

Scholars have advocated a rapprochement of the resourcebased view and the network view of organizations, suggesting that networks be viewed as an important firm resource (Gulati, Nohria, and Zaheer 2000; Madhavan, Koka, and Prescott 1998). Our findings support this. Much of the traditional literature on the resource-based view has suggested that value-creating resources must be owned and controlled by the firm (Barney 1991). This view has come under attack from theorists advocating that firms can generate value from market-based assets they do not own (Lavie 2007; Srivastava, Shervani, and Fahey 1998). Instead, firms can derive value from merely having access to resources. Our findings strongly support this latter idea and add the firm's 
network to the set of assets that can produce firm value. Although various scholars have suggested the possibility that networks contribute to alliance performance (e.g., Gulati 1998), empirical research is scarce. Our research bridges this gap and offers the following contributions.

First, given that network efficiency is viewed as a double-edged sword that can both strengthen and destroy value creation, our findings help clarify the level at which network efficiency can benefit the new alliance. Further research should offer stronger evidence regarding the mechanisms for how network efficiency creates these disparate effects. With better insight, further research could offer strategies for mitigating these problems, which might help firms proactively manage their networks.

Second, the literature on networks is rife with examples of how network density can both strengthen and weaken value creation. We find that at low to moderate levels, increasing network density improves value creation from marketing alliances. However, beyond moderate levels, increasing network density becomes detrimental to firm value. We argue that network density makes it difficult for the firm to customize its management of a given alliance, including the ability to selectively share information or resources. This behavior may be particularly important in the software business-a knowledge-based industry. Furthermore, given the intangible nature of the product, the compliance benefits of density may be less important to software firms because relationships are based on trust. If so, as firms embrace an ethic of open innovation, the benefits of dense networks should continue to decrease.

Third, prior research has found that network centrality and network reputation affect the probability of alliance formation (e.g., Gulati 1999). Our selection model results support these effects. However, we do not observe any additional effects on firm value creation beyond these partner selection effects. One explanation for these results resides in our measures. Further research could investigate the role of other types of network centrality (see Van den Bulte and Wuyts 2007). Given our focus on a firm's ego network, we use degree centrality. Other measures of network centrality (e.g., betweenness, closeness, eigenvector) are also worth examining. For example, betweenness centrality, a measure of the degree to which the firm is "in the middle of things," provides information about the firm's ability to manage resource flows. This may influence the firm's ability to generate more value from network partners. Likewise, other measures of firm reputation could be used to provide a stronger test.

Beyond measurement challenges, there may be more fundamental reasons for these null effects. Burt (1980) distinguishes between relational and positional advantages in a network. Centrality and reputation represent the positional network properties (i.e., size and status indicators). For example, when a firm is central, it has more relationships, and when it is in a high-reputation network, it has more status. These positional characteristics influence the value of the new alliance through greater partner selectivity, but not through partner management. Conversely, relational characteristics affect both partner selection and management. These findings are consistent with the works of Baum,
Calabrese, and Silverman (2000), who find that network efficiency is more important to biotech start-ups than the size of a firm's network; Moran (2005), who observes that the nature, not the number, of ties is more important to performance; and Van den Bulte, Lievens, and Moenaert (2004), who conclude that density is more important than centrality in interorganizational networks.

Finally, our research is not without limitations. First, our focus is on firm abnormal returns in the event window surrounding the announcement, not in the long run. Although the value of the announcement is not discernible in the long run in our findings, this effect should be revealed in subsequent alliance announcements because of the network effects that accumulate. Second, consistent with recent developments in finance, further research could account for time-varying stock price volatility in estimating the abnormal returns at the time of alliance announcement (Brown and Warner 1985). Third, our event study approach is based on the assumption of efficient capital markets. Though not our focus, we expect that further research will continue to challenge and test the validity of this theory's assumptions.

A worthwhile extension of this research would be to consider the non-stock market impact of the moderating role of firm networks. This approach would be valuable in teasing out network effects due to increased revenue, lower costs, or increased innovation. Examining how interactions of marketing capability with network characteristics influence stock market returns is another worthwhile avenue for further research.

\section{Contributions to Marketing Practice}

Marketing alliances and outsourcing payoffs. Our findings provide evidence that marketing alliances create this value, even in high-tech industries in which the contribution of strategic marketing actions has been challenged (Dutta, Narasimhan, and Rajiv 1999). Thus, rather than being viewed as a sign of weakness (as previous researchers have indicated), marketing alliances should be viewed as a strength, as shown by the increase in abnormal stock returns to both partners in the marketing alliance. Furthermore, marketing alliances offer much more flexibility than joint ventures/mergers and acquisitions while offering the same benefits of access to new markets and customers.

This result is particularly important in a recessionary era marked by budget cuts and softening demand, in which companies are under pressure to improve productivity. Marketing alliances can be an effective mechanism for achieving productivity and growth. Through alliances, managers can combine or pool resources with other companies to outsource aspects of their own firm that are peripheral to their core competencies. This notion of "shrinking the core and expanding the periphery" (Gulati and Kletter 2005) highlights the value of outsourcing as a means to reduce costs associated with noncore activities while helping firms redirect resources to areas that are consistent with their competencies.

Managing marketing alliance capability as a firm asset. Rather than being a function of luck or serendipity, the 
results demonstrate that marketing alliance capability is a learned skill that firms can use to increase value from future marketing alliances. How should firms invest to build such a capability? Approaches range from having dedicated resources within the firms to help identify good marketing partners to designing capabilities to initiate, implement, maintain/grow, and dissolve marketing alliances in an effective manner.

Managing networks as firm assets. Networks are not just the product of a series of past alliances, they are also an important predictor of future alliance success. We offer managers three theoretical mechanisms by which specific firm network characteristic have this important future effect. Although further research will need to determine the exact nature of these effects, we point to network-toalliance transfers as a key mechanism marketers should examine. Specifically, the network can provide an avenue for transferring gains realized from a given alliance across industries, markets, customer groups, and geographic locations. This effect is of particular importance in marketing alliances, in which the primary goal is often to gain access to new markets. For example, if a firm wants to extract more value from a new product alliance, its ability to do so may depend on its access to other markets supplied by its network. This ability has become even more important in the last decade as firms have become leaner and their ability to leverage their own presence in various industries or markets has been reduced.

Several additional observations are important. First, some network characteristics affect partner selection, and others affect the expected value creation from the alliance. Second, in attending to the value created beyond partner selection, managers should attend to the relational properties (network efficiency and density), not to the centrality or status of networks. With regard to managing the relational properties, marketers should remain aware that the levels of network density and efficiency affect firm value.

Finally, given that both the firm's network and its alliance capability are developed over time, the firm will need to adopt a long-term strategy for developing and managing both. This long-term status is similar to what marketers face with other key marketing resources, including customer relationships and brand equity. Thus, as with the other marketing resources, networks will require marketers to be forward thinking and proactive in their management.

\section{Conclusion}

Software firms that announce marketing alliances generate positive abnormal returns. A firm's network of preexisting alliances can increase or decrease those returns in important ways. We suggest that this occurs because networks multiply alliance benefits, facilitate alliance compliance, and signal firm and alliance quality. Thus, networks not only make a firm more or less attractive to partners but also alter the expected value of a newly announced marketing alliance in predictable ways. Therefore, networks are key strategic resources that can yield substantial firm value. As such, the firm's network of alliance relationships can play a crucial role as a market-based asset in the firm's strategic arsenal.

\section{Appendix A Selection Model Procedure and Results}

The ideal selection test would involve creating a set of possible partners considered by the firm and then determining whether firm characteristics influence partner choice. Unfortunately, there is no way to reconstruct this set post hoc. As a surrogate, we created a list of potential partners within $\pm 25 \%$ of the selected partner's size in the same industry (based on the four-digit SIC code) and year. We assumed that these firms $(n=2285)$ are a reasonable proxy for the set of potential partners available to the firm at the time.

Ideally, the selection model should include all variables in the value creation model. Thus, we include all the alliance characteristics: (1) relative size of partners, (2) horizontal alliance, (3) repeat partnership, and (4) marketing alliance with product development. Among the firm characteristics, we include the following: (5) network centrality, (6) network density, (7) network density ${ }^{2}$, (8) network efficiency, (9) network efficiency ${ }^{2},(10)$ network reputation, (11) alliance experience, (12) marketing resources, and (13) marketing alliance capability.

The final part of the selection model-the partner network characteristics, partner alliance capability, and change in firm network characteristics due to the partnerrepresents the greatest challenge for nonselected partners. Specifically, this would involve collecting data on the sample of 2055 nonselected partners $(2285$ - 230 selected partners), which is nine times the size of our current sample. Furthermore, given that, on average, our selected partners have 82.32 direct partners (as reflected in centrality measures), constructing network measures for each of the nonselected partners would involve collecting $2055 \times$ 82.32 pieces of information for our network measures. Given this, we instead employed a proxy strategy for these measures.

We began by reviewing the literature for potential proxy variables related to our network variables. We then evaluated our own data to ensure that the variables we selected were reasonable. In the end, we adopted two proxies. First, we selected partner Tobin's q as a surrogate for partner network density. This is supported by our existing data in which firm and selected partner Tobin's q are correlated significantly with network density $(\rho=.20, p<.05)$. Second, we selected partner size (measured as the number of employees) as a surrogate for network centrality, reputation, efficiency, and alliance capability. In our data, firm size and selected partner size are correlated significantly with network centrality $(\rho=.40, p<.01)$, network reputation $(\rho=$ $.13, p<.05)$, network efficiency $(\rho=.18, p<.05)$, and alliance capability $(\rho=.15, p<.05)$. Given this evidence, we collected the size and Tobin's q of all the nonselected 
partners available to the firm in the industry and year and used these data in the selection model as proxies for the nonselected partners' network variables. ${ }^{9}$ Together with the 13 alliance and firm variables previously listed, these two partner variables constitute our selection equation estimated using a Probit model. The dependent variable is partner selection, which takes on a value of 1 if the partner was selected for a given alliance and 0 if otherwise. In the following equation, we model partner selection according to whether firm $\mathrm{i}$ selected a given partner $\mathrm{p}$ for alliance $\mathrm{k}$ at time t:

$$
\begin{aligned}
& \text { Partner Selection }_{\text {itk }}=\alpha_{0} \\
& \left.+\alpha_{1} \text { (Relative Size of Firm and Partner }\right)_{\mathrm{k}} \\
& +\alpha_{2}(\text { Horizontal Alliance })_{\mathrm{k}}+\alpha_{3}(\text { Repeat Partnering })_{\mathrm{k}} \\
& +\alpha_{4} \text { (Marketing Alliance with Product Development } \\
& \text { Component })_{\mathrm{k}}+\alpha_{5}(\text { Firm Network Centrality })_{\mathrm{it}} \\
& +\alpha_{6}(\text { Firm Network Efficiency })_{\text {it }} \\
& \left.+\alpha_{7}(\text { Firm Network Efficiency })^{2}\right)_{\text {it }} \\
& +\alpha_{8}(\text { Firm Network Density })_{\text {it }}+\alpha_{9}\left(\text { Firm Network Density }{ }^{2}\right)_{\text {it }} \\
& +\alpha_{10}(\text { Firm Network Reputation })_{\text {it }} \\
& +\alpha_{11}(\text { Firm Marketing Alliance Capability })_{\text {it }} \\
& \left.+\alpha_{12} \text { (Firm Marketing Resources) }\right)_{\text {it }} \\
& +\alpha_{13}(\text { Firm Alliance Experience })_{\mathrm{it}}+\alpha_{14}(\text { Partner Size })_{\mathrm{pt}} \\
& +\alpha_{15}(\text { Partner Tobin's q) })_{\mathrm{pt}}+\zeta_{\mathrm{it}},
\end{aligned}
$$

where $\mathrm{Y}=1$ when the partner was selected and $\mathrm{Y}=0$ when the partner was not selected. The error term in the selection equation, $\zeta_{i t}$, consists of three components represented as $\zeta(i, t)=e(i, t)+u(i)+w(t)$, where $u(i)$ is the firm effect, $\mathrm{w}(\mathrm{t})$ is the time effect, and $\mathrm{e}(\mathrm{i}, \mathrm{t})$ is the remaining error. Both firm and time effects are significant, and the proportion of the total variance contributed by the panel-level (firm and time effects) variance component in the selection model is $47 \%$.

The selection model accounts for heterogeneity due to firm and time effects with a random-effects model. Our final model uses a random-effects simultaneous model estimation procedure involving the selection model and the value creation model (Verbeek and Nijman 1992). The selectivity parameter in Table 3 accounts for the selection bias and is produced as a consequence of the simultaneous estimation of the selection and value creation models. Our selection model results appear in Table A1.

\footnotetext{
${ }^{9}$ We were not able to locate a good proxy for the "change in network" variables. However, given that the value creation model fails to find effects for these variables, and we find no correlation between them and the variables in the value creation model (see Table 1), it is reasonable to focus on the proposed selection model.
}

Table A1

Selection Model Results

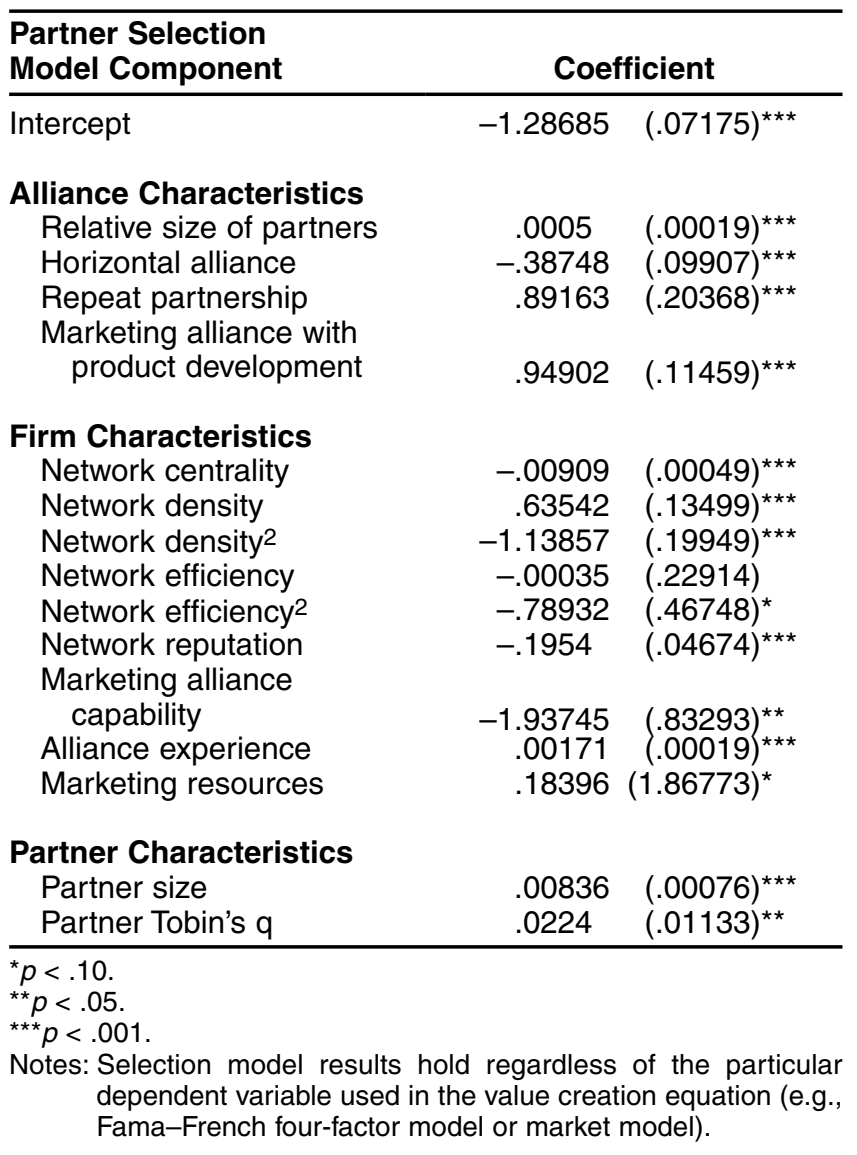

\section{Appendix B Robustness Checks}

\section{Are Results Robust to the Assignment of Focal Versus Partner Firm?}

"Focal firm" describes the firm that is our focus, and "partner firm" describes the other. Of 230 alliances, 46 horizontal alliance observations represented both sides of the dyad. Thus, the pooled sample consists of 414 alliances (184 focal firms +184 partner firms +46 horizontal alliances). For a pooled sample of focal firms and partners, the Fama-French four-factor model returns for event day -2 to event day +1 window are $1.4 \%(p<.01)$. The returns for the sample of partner firms alone are $1.2 \%$ and not different from the focal firm $(1.4 \%, \mathrm{t}=.37$, n.s. $)$, in support of $\mathrm{H}_{1}$. To test the remaining hypotheses, we reestimated the value creation model, and in general, the results are comparable. Specifically, network centrality and reputation are not significant, network density is positive $(\beta=.026, p<.05)$, network density 2 is marginally negative $(\beta=-.012, p<.10)$, network efficiency is positive $(\beta=.121, p<.01)$, network efficiency 2 is negative $(\beta=-.196, p<.01)$, focal firm alliance capability is positive $(\beta=.198, p<.01)$, and partner firm alliance capability is negative $(\beta=-.613, p<.01)$. Different from prior results, the impact of repeat partnering is now 
significant $(\beta=.149, p<.01)$. A Chow test of whether the results vary between focal and partner firm samples finds no differences $(F(25,389)=1.15$, n.s. $)$.

\section{Are Results Robust to Private Partners?}

Our sample included marketing alliances involving only public partners. We reestimated the model with marketing alliances involving both public and private partners by excluding two partner variables available for public firms (i.e., partner alliance capability and relative size). The results do not change.

\section{Are Results Robust to Alternative Influences on the Announcement?}

Because multiple marketing alliance announcements could be made by a firm in a year, we reestimated the model incorporating only the first marketing alliance announcement in the year. The resultant sample size of 189 announcements yielded similar results.

\section{Are Results Robust to Alternative Measures?}

Our measures of alliance capability used an exponentially smoothed model. Instead, we used the simple average change in firm abnormal returns, and the results do not change. We measured relative size using sales and number of employees, and the results do not change. We measured network reputation by summing, not averaging, across the network and by using different categorical versions, and the results do not change. Finally, we measured market model cumulative abnormal returns using value-weighted portfolios as a benchmark (rather than equal-weighted portfolio), and the results do not change.

\section{Do Marketing Alliance Announcements Have Long-Term Effects?}

We estimated the long-term effect using buy-and-hold return, Ibbotson returns across time and securities, and calendar-time portfolio models as outlined by Sorescu, Shankar, and Kushwaha (2007) and Markovitch and Golder (2008). The results indicate no effect on long-term abnormal returns, which may be due to several reasons. First, given that an alliance is a specific event, other intervening firm actions can obscure the long-term effect. Second, if the stock market is efficient, investor expectations are updated over time (Mizik and Jacobson 2003). As such, there is a weaker chance of observing the effect of the announcement as time passes. Third, if the stock market is efficient, expectations of the value of the alliance should be reasonably accurate, unless an alliance fails to meet expectations. However, our null effect indicates that no reversals occurred.

\section{Does Liquidity Risk Affect Firm Returns for Marketing Alliance Announcements?}

Liquidity risk may account for variation in returns (Sadka 2006). We reestimated our Fama-French four-factor model by including a liquidity factor, and the results are identical. The correlation between Fama-French four-factor and fivefactor returns is high $(\rho=.80)$.

\section{REFERENCES}

Achrol, Ravi and Philip Kotler (1999), "Marketing in the Network Economy," Journal of Marketing, 63 (Special Issue), 146-63.

Agrawal, Jagdish and Wagner A. Kamakura (1995), "The Economic Worth of Celebrity Endorsers: An Event Study Analysis," Journal of Marketing, 59 (July), 56-62.

Anand, Bharat N. and Tarun Khanna (2000), "Do Firms Learn to Create Value? The Case of Alliances," Strategic Management Journal, 21 (3), 295-315.

Anderson, Erin and Barton A. Weitz (1992), "The Use of Pledges to Build and Sustain Commitment in Distribution Channels," Journal of Marketing Research, 29 (February), 18-34.

Anderson, James C., Håkan Håkansson, and Jan Johanson (1994), "Dyadic Business Relationships Within a Business Network Context," Journal of Marketing, 58 (October), 1-15.

Antia, Kersi D. and Gary L. Frazier (2001), "The Severity of Contract Enforcement in Interfirm Channel Relationships," Journal of Marketing, 65 (October), 67-81.

Barney, Jay (1991), "Firm Resources and Sustained Competitive Advantage," Journal of Management, 17 (1), 99-120.

Bass, Frank M., P. Cattin, and Dick Wittink (1978), "Firm Effects and Industry Effects in the Analysis of Market Structure and Profitability," Journal of Marketing Research, 15 (February), 3-10.

Baum, Joel C., Tony Calabrese, and Brian S. Silverman (2000), "Don't Go It Alone: Alliance Network Composition and Startups' Performance in Canadian Biotechnology," Strategic Management Journal, 21 (3), 267-96.

Beckman, Christine M. and Pamela R. Haunschild (2002), "Network Learning: The Effects of Partners' Heterogeneity of Experience on Corporate Acquisitions," Administrative Science Quarterly, 47 (March), 92-124.
Bond, Edward U., Beth A. Walker, Michael D. Hutt, and Peter H. Reingen (2004), "Reputational Effectiveness in CrossFunctional Working Relationships," Journal of Product Innovation Management, 21 (January), 44-60.

Brown, Stephen J. and Jerold B. Warner (1985), "Using Daily Stock Returns: The Case of Event Studies," Journal of Financial Economics, 14 (1), 3-31.

Bucklin, Louis and Sanjit Sengupta (1993), "Organizing Successful Co-Marketing Alliances," Journal of Marketing, 57 (April), 32-46.

Burt, Ronald S. (1980), "Models of Network Structure," Annual Review of Sociology, 6, 79-141.

- (2000), "The Network Structure of Social Capital," in Research in Organizational Behavior, Robert I. Sutton and Barry M. Staw, eds. Greenwich, CT: JAI Press, 345-423.

(2004), "Structural Holes and Good Ideas," American Journal of Sociology, 110 (2), 349-99.

Capaldo, Antonio (2007), "Network Structure and Innovation: The Leveraging of a Dual Network as a Distinctive Relational Capability," Strategic Management Journal, 28 (March), 585-608.

Carhart, Mark M. (1997), "On Persistence in Mutual Fund Performance," Journal of Finance, 52 (1), 57-82.

Cohen, Wesley M. and Daniel Levinthal (1990), "Absorptive Capacity: A New Perspective on Learning and Innovation," Administrative Science Quarterly, 35 (1), 128-52.

Coleman, James S. (1988), "Social Capital in the Creation of Human Capital," American Journal of Sociology, 94 (July), 95-120.

(1990), Foundations of Social Theory. Cambridge, MA: Harvard University Press. 
Cook, Douglas O., Robert Kieschnick, and Robert A. Van Ness (2006), "On the Marketing of IPOs," Journal of Financial Economics, 82 (March), 35-61.

Das, Somnath, Pradyot K. Sen, and Sanjit Sengupta (1998), "Impact of Strategic Alliances on Firm Valuation," Academy of Management Journal, 41 (1), 27-41.

Drukker, David M. (2003), "Testing for Serial Correlation in Linear Panel-Data Models," Stata Journal, 3 (June), 168-77.

Dutta, Shantanu, Om Narasimhan, and Surendra Rajiv (1999), "Success in High-Technology Markets: Is Marketing Capability Critical?" Marketing Science, 18 (4), 547-68.

Dwyer, F. Robert, Paul H. Schurr, and Sejo Oh (1987), "Developing Buyer-Seller Relationships," Journal of Marketing, 51 (April), 11-27.

Fama, Eugene and Kenneth R. French (1993), "Common Risk Factors in Returns to Stocks and Bonds," Journal of Financial Economics, 33 (1), 3-56.

and - (1996), "Multifactor Explanations of Asset Pricing Anomalies," Journal of Finance, 51 (1), 55-84.

Freeman, Linton (1979), "Centrality in Social Networks: Conceptual Clarification," Social Networks, 1 (February), 215-39.

Frels, Judy K., Tasadduq Shervani, and Rajendra K. Srivastava (2003), "The Integrated Networks Model: Explaining Resource Allocations in Network Markets," Journal of Marketing, 67 (January), 29-45.

Galaskiewicz, Joseph (1985), "Interorganizational Relationships," Annual Review of Sociology, 11, 281-304.

Geyskens, Inge, Katrijn Gielens, and Marnik G. Dekimpe (2002), "The Market Valuation of Internet Channel Additions," Journal of Marketing, 66 (April), 102-119.

Goerzen, Anthony (2007), "Alliance Networks and Firm Performance: The Impact of Repeated Partnerships," Strategic Management Journal, 28 (February), 487-509.

and Paul W. Beamish (2005) "The Effect of Alliance Network Diversity on Multinational Enterprise Performance," Strategic Management Journal, 26 (4), 333-54.

Granovetter, Mark (1973), "The Strength of Weak Ties," American Journal of Sociology, 78 (6), 1360-80.

Grewal, Rajdeep, Gary Lilien, and Girish Mallapragada (2006), "Location, Location, Location: How Network Embeddedness Affects Project Success in Open Source Systems," Management Science, 52 (7), 1043-1157.

Gulati, Ranjay (1998), "Alliances and Networks," Strategic Management Journal, 19 (4), 293-317.

(1999), "Network Location and Learning: The Influence of Network Resources and Firm Capabilities on Alliance Formation," Strategic Management Journal, 20 (50), 397-420.

— and Martin Gargiulo (1999), "Where Do Interorganizational Networks Come From?" American Journal of Sociology, 104 (5), 1439-93.

— and David Kletter (2005), "Shrinking Core, Expanding Periphery: The Relational Architecture of High-Performing Organizations," California Management Review, 47 (3), 77-104.

_, Nitin Nohria, and Akbar Zaheer (2000), "Strategic Networks," Strategic Management Journal, 21 (3), 203-215.

Heide, Jan B. (1994), "Interorganizational Governance in Marketing Channels," Journal of Marketing, 58 (January), 71-85.

- Kenneth H. Wathne, and Aksel I. Rokkan (2007), "Interfirm Monitoring, Social Contracts, and Relationship Outcomes," Journal of Marketing Research, 44 (August), 425-33.

Hitt, Michael A., Tina M. Dacin, Edward Levitas, Jean-Luc Arregle, and Anca Borza (2000), "Partner Selection in Emerging and Developed Market Contexts: Resource-Based and Organizational Learning Perspectives," Academy of Management Journal, 43 (3), 449-67.

Houston, Mark B. and Shane A. Johnson (2000), "Buyer-Supplier Contracts Versus Joint Ventures: Determinants and Conse- quences of Transaction Structure," Journal of Marketing Research, 37 (February), 1-15.

- Christine Moorman, Peter H. Reingen, Aric Rindfleisch, Vanitha Swaminathan, and Beth Walker (2004), "A Network Perspective on Marketing Strategy Performance," in Assessing Marketing Strategy Performance, Christine Moorman and Donald R. Lehmann, eds. Cambridge, MA: Marketing Science Institute, 247-68.

Kalaignanam, Kartik, Venkatesth Shankar, and Rajan Varadarajan (2007), "Asymmetric New Product Development Alliances: Win-Win or Win-Lose Partnerships?" Management Science, 53 (3), 357-74.

Kale, Prashant, Jeffrey Dyer, and Harbir Singh (2002), "Alliance Capability, Stock Market Response, and Long-Term Alliance Success: The Role of the Alliance Function," Strategic Management Journal, 23 (8), 747-67.

Khanna, Tarun, Ranjay Gulati, and Nitin Nohria (1998), “The Dynamics of Learning Alliances: Competition, Cooperation and Relative Scope," Strategic Management Journal, 19 (3), 193-210.

Koh, Jeongsuk and N. Venkatraman (1991), "Joint Venture Formations and Stock Market Reactions: An Assessment in the Information Technology Sector," Academy of Management Journal, 34 (4), 869-92.

Kreps, David M. (1990), Game Theory and Economic Modeling. Oxford: Oxford University Press.

Lavie, Dovev (2007), "Alliance Portfolios and Firm Performance: A Study of Value Creation and Appropriation in the U.S. Software Industry," Strategic Management Journal, 28 (12), 1187-1212.

Lee, Gwendolyn (2007), "The Significance of Network Resources in the Race to Enter Emerging Product Markets: The Convergence of Telephony Communications and Computer Networking 1989-2001," Strategic Management Journal, 28 (1), 17-37.

Luo, Xueming, Aric Rindfleisch, and David K. Tse (2007), "Working with Rivals: The Impact of Competitor Alliances on Financial Performance," Journal of Marketing Research, 44 (February), 73-83.

Madhavan, Ravindranath, Balaji R. Koka, and John E. Prescott (1998), "Networks in Transition: How Industry Events (Re)shape Interfirm Relationships," Strategic Management Journal, 19 (5), 439-59.

Markovitch, Dmitri G. and Peter Golder (2008), "Using Stock Prices to Predict Market Events: Evidence on Sales Takeoff and Long-Term Firm Survival," Marketing Science, 27 (4), 717-29.

Megginson, William L. and Kathleen A. Weiss (1991), "Venture Capitalist Certification in Initial Public Offerings," Journal of Finance, 46 (3), 879-903.

Mizik, Natalie and Robert Jacobson (2003), "Trading Off Between Value Creation and Value Appropriation: The Financial Implications of Shifts in Strategic Emphasis," Journal of Marketing, 67 (January), 63-76.

Moeller, Sara B., Frederik Schlingemann, and Rene M. Stulz (2004), "Firm Size and the Gains from Acquisitions," Journal of Financial Economics, 73 (August), 201-228.

Moran, Peter (2005), "Structural vs. Relational Embeddedness: Social Capital and Managerial Performance," Strategic Management Journal, 26 (12), 1129-51.

Palmatier, Robert W. (2008), Relationship Marketing. Cambridge, MA: Marketing Science Institute.

Peteraf, Margaret A. (1993), "The Cornerstones of Competitive Advantage: A Resource-Based View," Strategic Management Journal, 14 (3), 179-91.

Podolny, Joel M. (1993), "A Status-Based Model of Market Competition," American Journal of Sociology, 98 (4), 829-72. 
and Toby E. Stuart (1995), "A Role-Based Ecology of Technological Change," American Journal of Sociology, 100 (5), 1224-60.

Powell, Walter W., Kenneth W. Koput, and Laurel Smith-Doerr (1996), "Interorganizational Collaboration and the Locus of Innovation: Networks of Learning in Biotechnology," Administrative Science Quarterly, 41 (1), 116-46.

Rao, Akshay, Lu Qu, and Robert W. Ruekert (1999), "Signaling Unobservable Product Quality Through a Brand Ally," Journal of Marketing Research, 36 (May), 258-68.

Raub, Werner and Jeroen Weesie (1990), "Reputation and Efficiency in Social Interactions: An Example of Network Effects," American Journal of Sociology, 96 (3), 626-54.

Rindfleisch, Aric and Jan B. Heide (1997), "Transaction Cost Analysis: Past, Present, and Future Applications," Journal of Marketing, 61 (October), 30-54.

and Christine Moorman (2001), "The Acquisition and Utilization of Information in New Product Alliances: A Strength of Ties Perspective," Journal of Marketing, 65 (April), 1-18.

Rowley, Tim, Dean Behrens, and David Krackhardt (2000), "Redundant Governance Structures: An Analysis of Structural and Relational Embeddedness in the Steel and Semiconductor Industries," Strategic Management Journal, 21 (3), 369-87.

Rust, Roland T., Tim Ambler, Gregory S. Carpenter, V. Kumar, and Rajendra K. Srivastava (2004), "Measuring Marketing Productivity: Current Knowledge and Future Directions," Journal of Marketing, 68 (October), 76-89.

Sadka, Ronnie (2006), "Momentum and Post-Earnings Announcement Drift Anomalies: The Role of Liquidity Risk," Journal of Financial Economics, 80 (2), 309-349.

Schilling, Melissa A. and Corey C. Phelps (2007), "Interfirm Collaboration Networks: The Impact of Large-Scale Network Structure on Firm Innovation," Management Science, 53 (7), 1113-26.

Scott, John (1991), Social Network Analysis: A Handbook. Newbury Park, CA: Sage Publications.

Shah, Reshma H. and Vanitha Swaminathan (2008), "Factors Influencing Partner Selection in Strategic Alliances: The Moderating Role of Alliance Context," Strategic Management Journal, 29 (5), 471-94.

Sorescu, Alina, Venkatesh Shankar, and Tarun Kushwaha (2007), "New Product Preannouncements and Shareholder Value: Don't Make Promises You Can't Keep," Journal of Marketing Research, 44 (August), 468-89.
Srivastava, Rajendra, Tasadduq A. Shervani, and Liam Fahey (1998), "Market-Based Assets and Shareholder Value: A Framework for Analysis," Journal of Marketing, 62 (January), $2-18$.

Swaminathan, Vanitha, Feisal Murshed, and John Hulland (2008), "Value Creation Following Merger and Acquisition Announcements: The Role of Strategic Emphasis Alignment," Journal of Marketing Research, 45 (February), 33-47.

Tellis, Gerard J. and Joseph Johnson (2007), "The Value of Quality," Marketing Science, 26 (November-December), 758-73.

Tsai, Wenpin and Sumantra Ghoshal (1998), "Social Capital and Value Creation: The Role of Intrafirm Networks," Academy of Management Journal, 41 (4), 464-76.

Uzzi, Brian (1996), "The Sources and Consequences of Embeddedness for the Economic Performance of Organizations," American Sociological Review, 61 (4), 674-98.

(1997), "Social Structure and Competition in Interfirm Networks: The Paradox of Embeddedness," Administrative Science Quarterly, 42 (1), 37-69.

Van den Bulte, Christophe, Annouk Lievens, and Rudy K. Moenaert (2004), "Market Knowledge Spillovers and Differential Absorption Within Marketing Departments," working paper, Wharton School, University of Pennsylvania.

- and Stefan Wuyts (2007), Social Networks and Marketing. Cambridge, MA: Marketing Science Institute.

Verbeek, Marno and Theo Nijman (1992), "Testing for Selectivity Bias in Panel Data Models," International Economic Review, 33 (3), 681-703.

Walker, Gordon, Bruce Kogut, and Weijian Shan (1997), "Social Capital, Structural Holes and the Formation of an Industry Network," Organization Science, 8 (2), 109-125.

Webster, Frederick E., Jr. (1992), "The Changing Role of Marketing in the Corporation," Journal of Marketing, 56 (October), $1-17$.

Wooldridge, Jeffrey M. (2002), Econometric Analysis of Cross Section and Panel Data. Cambridge, MA: MIT Press.

Workman, John P., Jr. (1993), "Marketing's Limited Role in New Product Development in One Computer Systems Firm," Journal of Marketing Research, 30 (November), 405-422.

Wuyts, Stefan, Stefan Stremersch, and Shantanu Dutta (2004), "Portfolios of Interfirm Agreements in Technology-Intensive Markets: Consequences for Innovation and Profitability," Journal of Marketing, 68 (April), 88-100. 